\title{
The Correlation Between Parents' Self-Determination with Behavioral Prevention of Picky Eating in Toddlers
}

Indonesian Nursing Journal of Education and Clinic (INJEC)

I52-157

Volume 5, Issue 2, December 2020

DOI: I0.24990/injec.v5i2.310

injec.aipni-ainec.org/index.php/INJEC/index

Received : 2020-06-29

Accepted : 2020-08-23

The Association of Indonesian Nurse

Education Center (AINEC)

\section{Dona Muji Fitriana' $\mathbb{D}$, Yuni Sufyanti Arief ${ }^{\prime}(\mathbb{D}$, Ilya Krisnana 'D}

\begin{abstract}
Introduction: Picky eating is a disorder in eating patterns which is currently found in toddlers and parents have an important role in shaping the eating behavior of children. The purpose of this study was to determine the correlation of parents' self-determination with the behavioral prevention of picky eating in toddlers.

Methods: This study is a correlational analytic study with cross-sectional design. The independent variable in this study is parents' self-determination and the dependent variable is behavioral prevention of picky eating. The population was parents with toddlers in the working area at the Public Health Center of Kedawung I, Sragen, Central Java. A sample of II3 respondents was selected by cluster sampling. Data were collected using questionnaires demographic of the respondent, Basic Psychological Need Satisfaction and Frustration Scale/BPNSFS, and behavioral prevention of picky eating which was then analyzed using the Spearman-rank test.

Results: Based on the characteristics, the majority of respondents are aged 2I-39 years old, educated from junior to senior high, working as a housewife, and have a family income each month was less than the minimum wage of work. The results showed that most parents with self-determination in the good category correlate positively with the behavioral prevention of picky eating in their children ( $P$ value $=0.000, r$-value $=0.487$ ).

Conclusion: Parents with self-determination in the good category also have good behavioral prevention of picky eating. The result of this study could be used by nurses to reference in health promotion into the prevention of picky eating in children.
\end{abstract}

\section{Keywords}

parents, picky eating, self determination

\section{INTRODUCTION}

Along with the development of the times, many factors can influence a child's nutritional status, including parenting, exclusive breastfeeding, parental characteristics, and family environment. Children prefer to eat junk food (Rusilanti, Dahlia, \& Yulianti, 2015) and tend to behave in picky eating or fussy eating (Chao, 20l8). Some studies explain that picky eating is a matter of eating where children behave picky about food or limit the amount and variety of food, both in foods that are already known or in certain types or groups of foods, such as foods that are rich in fiber,

\footnotetext{
${ }^{1}$ Faculty of Nursing, Universitas Airlangga, Surabaya - Indonesia

Corresponding Author:

Dona Muji Fitriana, Faculty of Nursing, Universitas Airlangga, Surabaya - Indonesia

Universitas Airlangga Kampus C, Jl. Mulyorejo, Mulyorejo, Surabaya, Kota SBY, Jawa Timur 60II5

Email: dona.muji.fitriana-2018@fkp.unair.ac.id
} 
vitamin C, magnesium, protein, zinc, and iron, meat, fish, certain fruits and vegetables and other micronutrients (Chao, 2018; Taylor, Northstone, Wernimont, \& Emmett, 2016). Children with picky eating are at risk of having problems with nutritional status, because a child who is picky eating tends to lack the nutrients contained in the food rejected. Picky eating behavior, if left unchecked, can result in a lack of protein energy, obesity, emotional sensitivity in some children and the frequency of food intake, which can lead to impaired growth of children due to prolonged nutritional problems (Kementerian Kesehatan RI, 2016; Rusilanti et al., 2015; Sandvik et al., 2018).

Picky eating in children is a global problem; the lack of proportion of fruit and vegetable consumption in population aged $\geq 5$ years in Indonesia has increased 2\% from 2013 with a total of $93.5 \%$ to $95.5 \%$ in 2018 . One of the effects of picky eating can be seen from the data of underweight and very underweight, as much as $10.2 \%$ in 2018 , which is still higher than the WHO target, and the obesity rate is still high at $8 \%$. Central Java has a stunting prevalence in 2018 (31.2\%) which is $1.6 \%$ higher than the national figure of $30.8 \%$ (Kementerian Kesehatan RI, 20I8).

The occurrence of picky eating behavior originates from changes in eating patterns of Indonesian people that range significantly from healthy eating patterns to unhealthy, and changing daily nutritional intake to become inadequate, which causes an increased risk of non-communicable diseases (Kementerian Kesehatan RI, 20I6). The desire to consume practical food and delicious foods such as junk food and soft drinks often reduces the time to eat fruits and vegetables and healthy foods that are actually more beneficial for the body ( $\mathrm{Li}$ et al., 20I6). This behavior causes parents to tend to let their children eat only preferred foods, such as junk food or sweet foods, so that children want to eat and do not try to accustom food that is shunned by their children (Scaglioni et al., 2018).

Regarding the current diet of the people, one of the factors that influence picky eating behavior is the environment of feeding at home (Rusilanti et al., 20/5), such as the use of television during meals, the absence of written eating rules in the home and the relaxation of parents in feeding children (Levene \& Williams,
2017; Luchini, Musaad, Lee, \& Donovan, 2017). Parents play an important role in promoting healthy food to children, but parents with economic problems tend to offer unhealthy foods that are only preferred by their children so as not to be a waste (Harris et al., 2019). The ability of parents to identify and achieve goals as parents is based on the knowledge and assessment of individuals against themselves, commonly called self-determination, is considered important (Girelli, Manganelli, \& Lucidi, 2016), because when parents as individuals have the freedom to choose certain health behaviors, they are more motivated to maintain these behavioral changes. This is in accordance with the theory of selfdetermination, which states that the expected behavior will be able to last a long time if someone has motivation in themselves that can affect the attitude of autonomy, so as to realize health behavior (Ross \& Barnes, 20I8).

Based on the explanation above, it is necessary to identify factors related to selfdetermination of parents in the prevention of picky eating in toddler age children.

\section{MATERIALS AND METHODS}

This research used correlational analytic with cross-sectional approach. The location in this study was in the working area at the Public Health Center of Kedawung, especially in Wonokerso and Wonorejo village from January until February 2020. The independent variable in this research is parents' selfdetermination and the dependent variable is behavioral prevention of picky eating. The population in this research is parents with toddlers in the working area at Public Health Center of Kedawung. The number of samples in this study was I I 3 respondents who met the inclusion and exclusion criteria and who were selected using cluster sampling based on integrated health posts. The inclusion criteria are parents who have toddlers and parents who care for their children for more than 12 hours. The exclusion criteria were parents who can't read, children who come to the integrated health post without their parents, and toddlers who aren't nurtured by their parents.

Data were collected by following the integrated health post schedule in Wonorejo and Wonokerso villages from January until 
February 2020, using a modification questionnaire from Health Promotion Model and Basic Psychological Need Satisfaction and Frustration Scale/BPNSFS (Chen, Vansteenkiste, Beyers, \& Boone, 2015). This questionnaire has a validity value of $0.50 \mathrm{I}-$ 0.973 and a reliability value of 0.892 which was tested using Cronbach's alpha. Before collecting data, the researcher gave informed consent forms to parents which contained the purpose of conducting the research, the treatment given to the respondent, the benefits of the research to the respondent, the dangers that might occur, the right to refuse or agree to become a respondent, payment, and information about the researcher. Parents with toddlers filled out a questionnaire developed by the researcher and assisted by the researcher while waiting for their child to finish measuring their weight. The result of the questionnaire of parents' self-determination and behavioral prevention of picky eating is said to be in the good category if it has an average of $>75 \%, 56-75 \%$ is enough, and is less than $\leq 55 \%$. Data analysis of this study used the Spearman-rank test with a significance $p>0.005$. This research has received permission from the Faculty of Nursing Universitas Airlangga ethics commission, with number I873-KEPK on January 3, 2020.

\section{RESULTS}

The results of the demographic characteristic of respondents in this study were obtained from the data collection; age, ethnicity, education, occupation, and income can be seen in the table I. Table I shows that the majority of respondents aged 21-39 years were $68.1 \%$. Respondents were all Javanese, most were only educated last up to junior high

Table I. Demographic characteristics: age, ethnicity, education, occupation, and parents income $(n=113)$

\begin{tabular}{lll}
\hline Characteristics & $\mathrm{n}$ & $\%$ \\
\hline Age & 28 & \\
16-20 years & 77 & 68.8 \\
21-39 years & 8 & 7.1 \\
40-59 years & & \\
Ethnicity & 113 & 100 \\
Javanese & & \\
Education & 7 & 6.2 \\
Primary School & 49 & 43.4 \\
Junior High School & 47 & 41.6 \\
Senior High School & 10 & 8.8 \\
Bachelor & & \\
Occupation & 9 & 8.0 \\
Farmers & 35 & 31.0 \\
Employee & 44 & 38.9 \\
Does Not Work & 25 & 22.1 \\
Entrepreneur & & \\
Income & 31 & 27.4 \\
$>1.600 .000$ & 82 & 72.6 \\
$<1.600 .000$ & & \\
\hline
\end{tabular}

Table 2. Correlation between self-determination with behavioral prevention of picky eating

\begin{tabular}{|c|c|c|c|c|c|c|c|c|}
\hline \multirow{3}{*}{$\begin{array}{l}\text { Self- } \\
\text { determination }\end{array}$} & \multicolumn{8}{|c|}{ Prevention of picky eating } \\
\hline & \multicolumn{2}{|c|}{ Good } & \multicolumn{2}{|c|}{ Enough } & \multicolumn{2}{|c|}{ Less } & \multirow{2}{*}{ r } & \multirow{2}{*}{$\mathrm{p}$} \\
\hline & $\mathrm{f}$ & $\%$ & $\mathrm{f}$ & $\%$ & $\mathrm{~F}$ & $\%$ & & \\
\hline Good & 54 & 47.8 & 32 & 28.3 & 3 & 2.7 & \multirow{3}{*}{0.487} & \multirow{3}{*}{0.000} \\
\hline Enough & 2 & 1.8 & 8 & 7.1 & 1 & 0.9 & & \\
\hline Less & 1 & 0.9 & 4 & 3.5 & 8 & 7.1 & & \\
\hline
\end{tabular}


school as much as $43.4 \%$, the majority of respondents did not work or were as housewives and family income each month was less than the minimum wage of work, which was $72.6 \%$.

Correlation between parents' selfdetermination with behavioral prevention of picky eating in toddlers can be seen in Table 2. Table 2 shows that more parents that have self-determination in good categories also have behavioral prevention of picky eating in good categories, with a percentage of $47.8 \%$. Selfdetermination has a significant correlation to behavioral prevention of picky eating and has a positive coefficient.

\section{DISCUSSIONS}

The result of this study showed that most respondents had self-determination in the good category in behavioral prevention of picky eating toddlers. The correlation coefficient is positive, which means that the higher the parents' self-determination can make the higher behavioral prevention of picky eating toddlers. Self-determination is the basic psychological needs of individuals in increasing motivation that is more autonomous and can be supported by the social environment, making individuals have more motivation to change or maintain a behavior. In selfdetermination it is stated that the underlying components consist of three psychological needs, autonomy, competence, and relatedness. This research is supported by the explanation that the self-determination theory (SDT) is considered a solid approach so that it can be considered in behavior related to health promotion (Ryan \& Deci, 2017).

The result showed that more parents who have good self-determination also had good prevention of picky eating behaviors. The assessment of self-determination of parents is seen from the intrinsic motivation of parents in providing healthy and nutritious food to their children and to prevent their children from picky eating behavior. This is in line with selfdetermination theory which states that the expected behavior will be able to last a long time if someone has motivation in themselves that can affect the attitude of their autonomy, so as to realize health behavior (Patrick \& Williams, 20I2). Parents can prevent picky eating in their children if they use more autonomous support in providing new foods and have strong family support for preventing children from rejecting certain types of food (Fries, Martin, \& Horst, 20I7). In the efforts to promote healthy foods at home, parents have several obstacles both within themselves and from the environment. including such as busy parents so that there is no time, the cost of preparing healthy food in the house, the high desire of children to consume junk food, and the lack of support from the family because several other family members also have picky eating behavior (Levene \& Williams, 2017). Some parents think that by continuing to provide food that children dislike it causes waste (Harris et al., 2019).

The importance of motivating parents to minimize these disorders can prevent picky eating in toddlers. Need for motivation as well as a better understanding of parents about how to encourage meat, seeds, fruits, and vegetables to be included in food intake in children will help promote healthy eating habits (Edelson, Mokdad, \& Martin, 2016). The ability of parents to identify and achieve goals as parents, which is based on an individual's knowledge and assessment of himself or socalled self-determination, is considered important (Girelli et al., 2016), because, when parents as individuals have the freedom to choose certain health behaviors, they are more motivated to maintain these behavioral changes.

Parents' self-determination has a correlation with behavioral prevention of picky eating in toddlers. With the existence of selfdetermination in parents, it is hoped that it can create behavioral prevention of picky eating by toddlers so that it does not cause future nutritional problems.

\section{Limitation}

The categorization of nutritional status in children only determined by the indicator -2 SD. The authors did not accompany all respondents to fill the questionnaire so that the answers given are not completely objective.

\section{CONCLUSION}

Parental self-determination correlates with behavioral prevention of picky eating in 
toddlers. Good self-determination can make good behavioral prevention of picky eating. The result of this study can be used as information and reference for a nurse to determine the intervention in parents related to prevention of picky eating behavior so that there is no problem in the nutritional status of toddler age children and it does not have an impact on the rest of the child's life. Future studies are expected to examine other factors that can affect parental self-determination in behavioral prevention of picky eating.

\section{Acknowledgement}

The authors would like to thank the respondents who helped in this research and all who have participated to finish this research up to writing this manuscript.

\section{Conflict of Interest}

All researchers have no conflict of interest related to this study.

\section{REFERENCES}

Chao, H.-C. (20I8). Association of Picky Eating with Growth, Nutritional Status, Development, Physical Activity, and Health in Preschool Children. Frontiers in Pediatrics, 6(February), I-9. https://doi.org/I 0.3389/fped.2018.00022

Edelson, L. R., Mokdad, C., \& Martin, N. (20I6). Prompts to eat novel and familiar fruits and vegetables in families with I-3 yearold children: Relationships with food acceptance and intake. Appetite, 99, 138148.

https://doi.org/l0.1016/j.appet.2016.01.01 5

Fries, L. R., Martin, N., \& Horst, K. Van Der. (2017). Physiology \& Behavior Parentchild mealtime interactions associated with toddlers' refusals of novel and familiar foods. Physiology \& Behavior, I-8. https://doi.org/10.1016/j.physbeh.2017.03. 001

Girelli, L., Manganelli, S., \& Lucidi, F. (2016). A Self-determination theory based intervention to promote healthy eating and physical activity in school-aged children. Cuadernos de Psicología Del Deporte, 16, I3-20.

Harris, H. A., Staton, S., Morawska, A., Gallegos, D., Oakes, C., \& Thorpe, K. (2019). A comparison of maternal feeding responses to child fussy eating in lowincome food secure and food insecure households.

Appetite. https://doi.org//0.1016/j.appet.2019.03.00 5

Kementerian Kesehatan RI. (2016). Buku panduan GERMAS (Gerakan masyarakan hidup sehat). Kementrian Kesehatan Republik Indonesia.

Kementerian Kesehatan RI. (2018). HASIL UTAMA RISKESDAS.

Levene, I. R., \& Williams, A. (20I7). Fifteenminute consultation in the healthy child: " My child is a fussy eater !" Arch Dis Child Educ Pract Ed 2013, I-7. https://doi.org/10.1 I36/archdischild-2016311787

Li, Z., van der Horst, K., Ma, D., Wang, P., Vinyes-Pares, G., Wang, J., ... EdelsonFries, L. R. (2016). Perceptions of Food Intake and Weight Status Among Parents of Picky Eating Infants and Toddlers in China: A Cross-sectional Study. Appetite, 108, 456-463. https://doi.org//0.1016/j.appet.2016.11.09 Luchini, V., Musaad, S., Lee, S., \& Donovan, S. M. (20I7). Observed differences in child picky eating behavior between home and childcare locations. Appetite, I/6, I23|3|.

https://doi.org//0.1016/j.appet.2017.04.02 I

Patrick, H., \& Williams, G. C. (20I2). SelfDetermination Theory: Its Application to Health Behavior and Complementarity with Motivational Interviewing. International Journal of Behavioral Nutrition and Physical Activity, 9(I), 18. https://doi.org// 0.1 I86/1479-5868-9-18

Ross, B. M., \& Barnes, D. M. (2018). SelfDetermination Theory With Application to Employee Health Settings. SAGE Journals, $\quad X X(X), \quad 1-6$. https://doi.org//0.1 I77/21650799/77498 63

Rusilanti, Dahlia, M., \& Yulianti, Y. (20I5). Gizi dan Kesehatan Anak Prasekolah. (P. Latifah, Ed.). Bandung: PT Remaja Rosdakarya. 
Ryan, R. M., \& Deci, E. L. (20|7). SelfDetermination Theory: Basic Psychological Needs in Motivation, Development, and Wellness. London: The Guilford Press.

Sandvik, P., Ek, A., Somaraki, M., Hammar, U., Eli, K., \& Nowicka, P. (20।8). Picky eating in Swedish preschoolers of different weight status: Application of two new screening cut-offs. International Journal of Behavioral Nutrition and Physical Activity, 15(I),

$1-12$. https://doi.org//0.1 I86/s/2966-0I8-0706-
Scaglioni, S., De Cosmi, V., Ciappolino, V., Parazzini, F., Brambilla, P., \& Agostoni, C. (2018). Factors Influencing Children's Eating Behaviours. Nutrients, 10(6), I-17. https://doi.org// 0.3390/nul0060706

Taylor, C. M., Northstone, K., Wernimont, S. M., \& Emmett, P. M. (2016). Picky eating in preschool children: Associations with dietary fibre intakes and stool hardness. Appetite, 100 , 263-27I. https://doi.org/I0.1016/j.appet.2016.02.02 I

0 